\section{Effect of Growth Hormone in Experimental Tooth Movement}

Jucienne Salgado Ribeiro' ${ }^{1}$ José Vinicius Bolognesi Maciel², Luégya Amorin Henriques Knop ${ }^{1}$, Maria Ângela Naval Machado ${ }^{3}$, Ana Maria Trindade Grégio $^{4}$, Elisa Souza Camargo ${ }^{1}$

\author{
'Dentistry Graduate Program/ \\ Orthodontics, PUCPR - \\ Catholic University of Paraná, \\ Curitiba, PR, Brazil \\ ${ }^{2}$ Department of Orthodontics, \\ UFRJ - Federal University of Rio de \\ Janeiro, Rio de Janeiro, RJ, Brazil \\ ${ }^{3}$ Dentistry Graduate Program/ \\ Pathology, UFPR - Federal University \\ of Paraná, Curitiba, PR, Brazil \\ ${ }^{4}$ Graduate Dentistry Program/ \\ Pharmacology, PUCPR - \\ Catholic University of Paraná, \\ Curitiba, PR, Brazil
}

Correspondence: Profa. Dra. Elisa Souza Camargo, Rua Imaculada Conceição, 1155, 80.215-901 Curitiba, PR, Brasil. Tel.: +55-41-3271-1637. e-mail: escamargo@uol.com.br

Key Words: human growth hormone, bone.

\section{Introduction}

Growth hormone (GH) is an important and powerful metabolic hormone that is secreted from cells in the anterior pituitary gland, influenced by several normal and patophysiological conditions. The molecular structure consists of a single polypeptide chain of 191 amino acids with two disulphide bridges and a molecular weight of 22 $\mathrm{kDa}(1)$ and has a plasmatic half-life between 15 and $20 \mathrm{~min}$ after secretion or intravenous injection. After subcutaneous or intramuscular administration, blood concentrations of $\mathrm{GH}$ reach a peak between 1 and $3 \mathrm{~h}$ after injection and fall to undetectable levels after $24 \mathrm{~h} \mathrm{(2)}$.

$\mathrm{GH}$ is one of the most important regulatory substances in bone growth and bone remodeling (3). Children with various forms of GH deficiency or other defects in the $\mathrm{GH}$ signal-transduction pathway typically do not reach their full potential of size and stature (4). Until recently, $\mathrm{GH}$ supply was too much limited to treat these patients, but the advent of commercial application of recombinant DNA technology increased the indication of treatment with systemic supply of $\mathrm{GH}$ (5). Currently, individuals with specific endocrinopathies, debilitations associated with AIDS, Turner syndrome, chronic kidney failure (6), chronic obstructive lung disease (7) and sepsis (8) use synthetic $\mathrm{GH}$ in their treatments.

This hormone is also used illicitly and without medical supervision to improve the performance of athletes and people training at gyms. One study has reported that 5\% of male American high-school students use or have used $\mathrm{GH}$ as an anabolic agent (1). Furthermore, $\mathrm{GH}$ may revert some changes associated with aging, which is associated with the reduction in the blood levels of this hormone, and its administration can cause increase in density and skin collagen and/or increase lean body mass, muscular mass and bone mass $(9,10)$.

Considering its wide indication and use as well as the consolidation of its anabolic and lipolytic effects, and its direct action on bone formation and resorption (11-13), one could question whether $\mathrm{GH}$ would have the competence to interfere in bone remodeling during experimental tooth movement. GH acts directly on the proliferation and differentiation of osteoblasts (3) thus stimulating bone turnover, causing the increase in protein synthesis and mineralization (14) and more specifically, the bone matrix proteins (3). However, there are no studies in the literature demonstrating whether there is any modification in bone remodeling induced by orthodontic treatment in individuals on $\mathrm{GH}$ supplementation.

Bone formation requires differentiated and active osteoblasts to synthesize the extracellular matrix that will support the mineralizing process (15). Orthodontic tooth movement produces tissue reactions that are associated not only with local factors related to teeth and occlusion, but also with systemic factors related to bone metabolism $(16,17)$.

The aims of this study were to verify the effect of $\mathrm{GH}$ by the quantification of osteoclasts, Howship lacunae and blood vessels in the periodontal ligament and by the analysis of collagen maturation during experimental tooth movement in Wistar rats. 


\section{Material and Methods}

The research protocol was approved by the institutional Ethics Committee for Animal Experimentation (Process \#395).

Eighty 12-week-old male Wistar rats (Rattus norvergicus albinus) weighing approximately $300-350 \mathrm{~g}$ from our instituition's experimental animal care facility were used. The animals were kept in plastic cages, between $19{ }^{\circ} \mathrm{C}$ and $22{ }^{\circ} \mathrm{C}$ and photoperiod of $12 \mathrm{~h}$ of light and 12 $\mathrm{h}$ of darkness to avoid alteration in the metabolic cycle, with water and food ad libitum.

The animals were randomly divided into 2 groups: control (CG) and experimental (EG). Group $C$ received saline at $0.5 \mathrm{~mL} / \mathrm{kg}$ daily to simulate stress suffered by the animals up to the moment of euthanasia after $3,7,14$ and 21 days. Group E received $1.33 \mathrm{mg}$ (4 IU) of Saizen ${ }^{\odot}$ growth hormone (Somatropina r-hGH; Lab. Serono, Aubonne, Switzerland). Daily applications of $0.1 \mathrm{IU} / \mathrm{kg}$ was administered subcutaneously in the abdominal area alternating between the right and left side, beginning one day before orthodontic appliance installation and continuing up to the moment of euthanasia, always at the same time of the day. To receive the appliance, the animals wt; mean volume $0.25 \mathrm{~mL} /$ animal) in the quadriceps muscle of the left lower limb.

The orthodontic appliance (Fig. 1) was made from the model proposed by Heller and Nanda (18), which consisted of a $9 \mathrm{~mm}$ closed nickel-titanium spring (G\&H ${ }^{\circledast}$ Wire Company, Hannover, Germany) and a 0.022 inch stainless steel wire tie to fix the spring to the first right molar and maxillary incisors, with a force of $30 \mathrm{cN}$, measured by a precision dynamometer (Dentaurum, Ispringen, Germany). After initial activation, the appliance was not reactivated during the experimental period, but its position was checked daily.

The animals were euthanized by an intraperitoneal overdose of anesthetic solution, the anatomic pieces containing the maxillary right first molar were dissected, removed, fixed in 10\% buffered formalin for $72 \mathrm{~h}$ and demineralized in a $4.13 \%$ EDTA solution for 12 weeks. Next, After demineralization, 4- $\mu$ m-thick cross-sectional serial sections were obtained from the alveolar bone crest up to the root apex and stained with Harris and Lison hematoxylin-eosin or picrosirius method for analysis by a single, calibrated operator blinded to the groups.

The hematoxylin-eosin method was used to recognize and count the number of blood vessels, osteoclasts and Howship lacunae present in the periodontal ligament (PDL) adjacent to the mesiobuccal roots of the maxillary right first molar. The slides were analyzed under light microscopy at an original magnification of 200x. The histological criteria used to identify osteoclastic cells were the presence of eosinophilic and multinucleate cells (19).

The slides stained with picrosirius were analyzed under polarized light microscopy at an original magnification of $100 \times$ to determine the structural changes in the collagen present in the new bone formation of trabecular matrix, adjacent to the traction side of the mesiobuccal root of the maxillary right first molar. This method allows an indirect assessment of the organization stage of the bone matrix based on the birefringence of the collagen fiber bundles. The mature collagen presented reddish tones while immature collagen was yellowish-green. The analysis was performed using Image-Pro Plus 4.5 imageanalysis software (Media Cybernetics, Silver Spring, MD, USA), which calculated the percentage of mature and immature collagen. Measurement was performed in a randomly selected field of each section, and a mean of the percentage for each animal was obtained.

The Kruskal Wallis test was used to compare the intergroup variables at a significance level of $5 \%$.

\section{Results}

\section{Control Group}

On the $3^{\text {rd }}$ day, PDL presented with disorganized collagen fiber (CF) bundles in the compression area, with a predominance of oval fibroblasts (FB) and intense vascularization (Fig. 2A, Table 1). An increase in the number of osteoclasts (OC) located inside the Howship lacunae (HL) and contiguous to the bone surface was observed. In the traction area, PDL exhibited stretched, oblique and parallel $\mathrm{CF}$ bundles among them with a predominance of fusiform $\mathrm{FB}$ and moderate vascularization (Fig. 2C, Table 1). Under

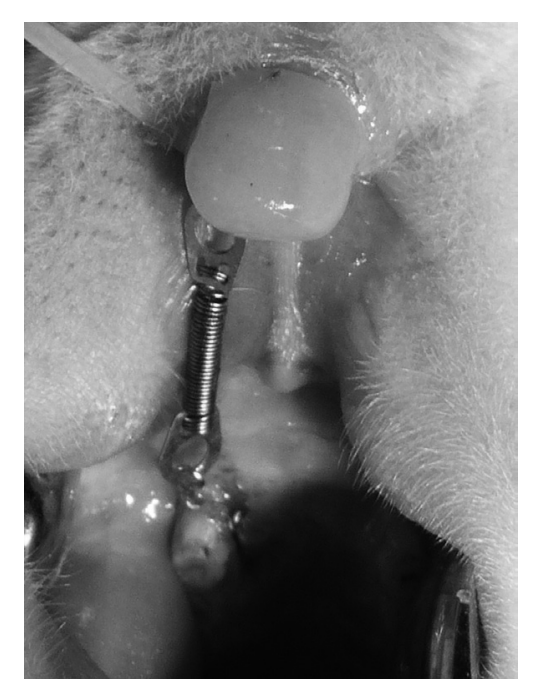

Figure 1. Orthodontic appliance fixed in the oral cavity of the rat. 
polarized light microcopy, there was a preponderance of immature collagen and the beginning of collagen matrix production (Table 2). After the initial stage of tooth movement, PDL thickness on both sides showed a trend towards normality on the $14^{\text {th }}$ and $21^{\text {st }}$ days. In the compression area, the $\mathrm{CF}$ bundles were disorganized with predominance of oval FB (Fig. 2E, I, M, Table 1) while in the traction area the $\mathrm{CF}$ bundles were stretched, oblique and parallel among them with predominance of fusiform FB dispersed in the matrix (Fig. 2G, K, O, Table 1). Gradual decrease occurred in the number of blood vessels (BV) from the $7^{\text {th }}$ up to the $21^{\text {st }}$ day with predominance in the number of $\mathrm{OC}$ on the $7^{\text {th }}$ day, which was not identified with the same frequency as in the earlier periods (Table1). In the analysis under polarized light, a greater organization and increase of mature $\mathrm{CF}$ with reddish coloration was observed on the $7^{\text {th }}$ day. Evidence of higher levels of collagen matrix synthesis, with expression of more organized fiber was found in the final stages of tooth movement (Table 2).

\section{Experimental Group}

From the $3^{\text {rd }}$ to the $21^{\text {st }}$ day, the compression and traction areas presented rare BV. In the compression area, the CF bundles were disorganized with predominance of oval $F B$, while in the traction area the bundles were stretched, oblique and parallel among them permeated by fusiform FB. The alveolar bone showed resorption units consisting of numerous $\mathrm{OC}$, showing intense resorptive activity on the $3^{\text {rd }}$ day (Fig. 2B, Table 1). Afterwards, the bone surface was irregular with the presence of $\mathrm{HL}$ containing $\mathrm{OC}$ on the $7^{\text {th }}$ and $14^{\text {th }}$ days (Fig. 2F, 2J, Table 1 ). On the $21^{\text {st }}$ day occasional $\mathrm{OC}$ and HL were observed (Fig. 2N, Table 1). Under polarized light microscopy, the matrix was constituted of mature collagen with more evident organizational level than in CG (Table 2).
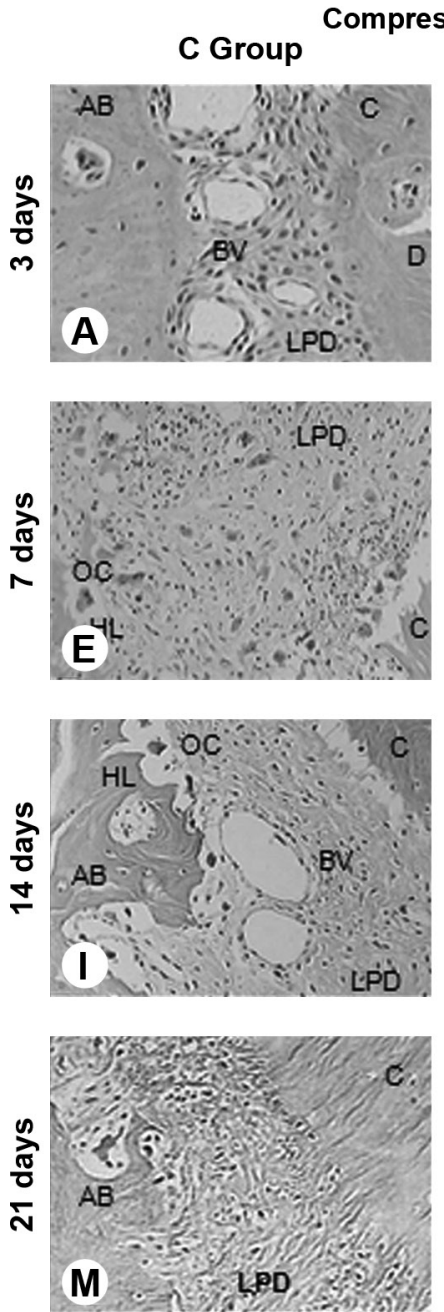

E Group
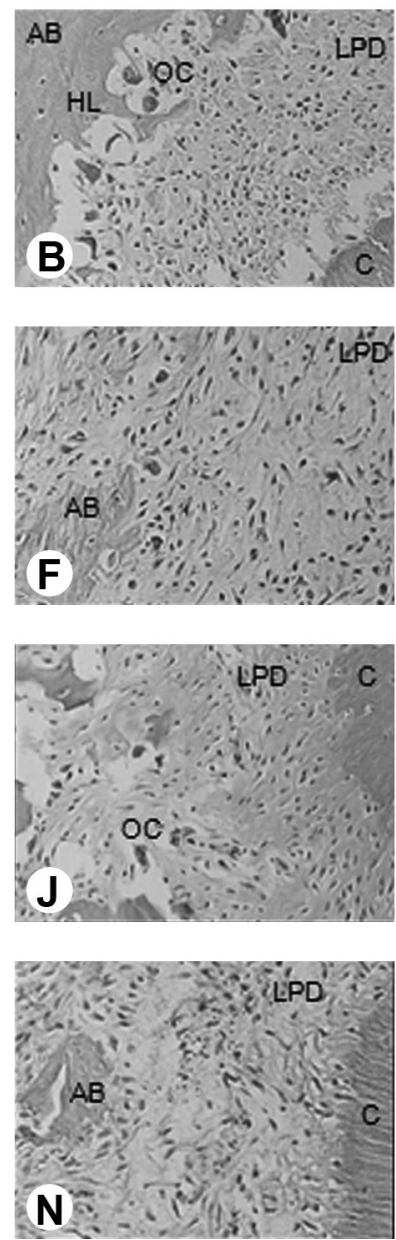

C Group
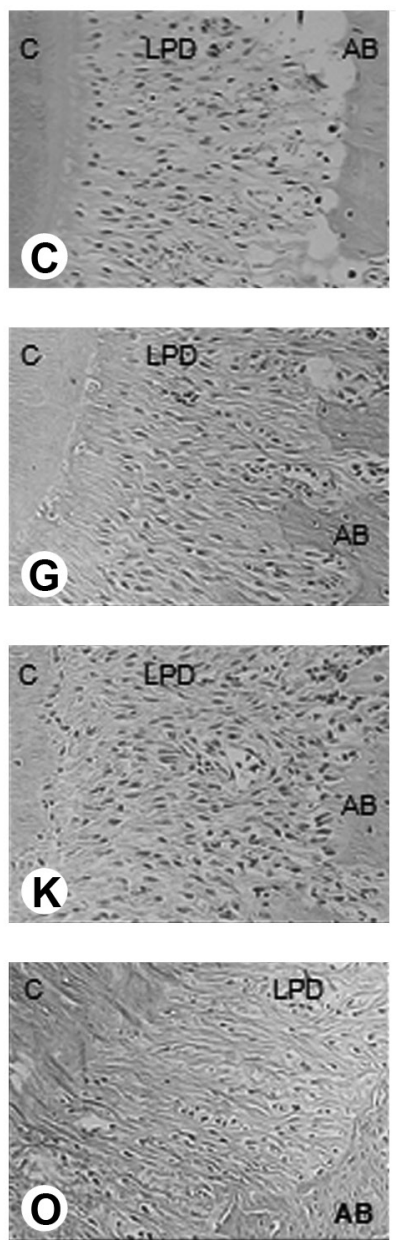

E Group
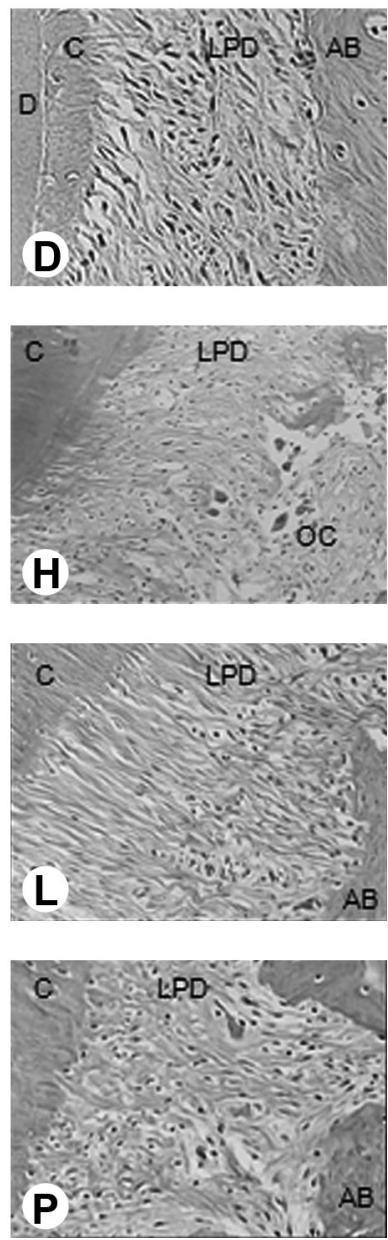

Figure 2. Compression (A, B, E, F, I, J, M, N) and traction area (C, D, G, H, K, L, O, P) of mesiobuccal roots of control group in $3^{\text {rd }}(A, C), 7^{\text {th }}(E, G)$, $14^{\text {th }}(1, K), 21^{\text {st }}$ day $(\mathrm{M}, 0)$ and of experimental group in $3^{\text {rd }}(B, D), 7^{\text {th }}(F, H), 14^{\text {th }}(\mathrm{J}, \mathrm{L})$ and $21^{\text {st }}$ day $(N, P)$. Cementum $(C)$, dentin $(D)$, alveolar bone (AB), periodontal ligament (PDL), blood vessel (BV), osteoclast (OC) and Howship lacunae (LH). HE, 200×. 
The morphological characteristics of tissues and cells found in group $\mathrm{C}$ correspond to a typical biological response to mechanical forces produced by the orthodontic tooth movement on PDL and alveolar bone, with reference to the studies of Heller and Nanda (18) and Macapanpan et al. (20). The comparison of this group with group E shows that the administration of $\mathrm{GH}$ induced dynamic changes in PDL and alveolar bone in experimentally moved rat teeth.

It must be considered that the $30 \mathrm{cN}$ force level selected for this study produced excellent force, because it caused effective induction of tooth movement without causing

Table 1. Results for the number of blood vessels, osteoclasts and Howship lacunae at the four evaluation periods and intergroup comparisons (Kruskal Wallis test, $p<0.05$ )

\begin{tabular}{|c|c|c|c|c|c|c|c|c|}
\hline \multirow{2}{*}{ Variable } & \multirow{2}{*}{ Day } & \multicolumn{3}{|c|}{ Control group } & \multicolumn{3}{|c|}{ Experimental group } & \multirow{2}{*}{$\begin{array}{c}\mathrm{p} \\
\text { value }\end{array}$} \\
\hline & & Mean & Median & S.D. & Mean & Median & S.D. & \\
\hline \multirow{4}{*}{ Osteoclasts } & 3 & 6.3 & 6.5 & 1.337 & 31.2 & 31.5 & 3.225 & $0.000^{*}$ \\
\hline & 7 & 16.9 & 17 & 3.348 & 19 & 19 & 4.714 & 1.000 \\
\hline & 14 & 3.3 & 3.5 & 1.059 & 14.8 & 14 & 2.348 & $0.036^{*}$ \\
\hline & 21 & 1.4 & 1 & 1.265 & 5.3 & 6 & 2.359 & 1.000 \\
\hline \multirow{4}{*}{$\begin{array}{l}\text { Howship } \\
\text { lacunae }\end{array}$} & 3 & 6.5 & 6.5 & 1.958 & 43.1 & 43.5 & 10.027 & $0.000^{*}$ \\
\hline & 7 & 17.8 & 17.5 & 2.573 & 24.8 & 23 & 7.068 & 1.000 \\
\hline & 14 & 3.9 & 4 & 1.197 & 15.7 & 14.5 & 4.398 & 0.145 \\
\hline & 21 & 1 & 1 & 0.943 & 5.2 & 5.5 & 2.616 & 1.000 \\
\hline \multirow{4}{*}{$\begin{array}{l}\text { Blood } \\
\text { vessels }\end{array}$} & 3 & 25.5 & 25.5 & 1.958 & 0.7 & 0.5 & 0.949 & $0.000^{*}$ \\
\hline & 7 & 7.1 & 7 & 1.449 & 0.8 & 0 & 1.135 & $0.000^{*}$ \\
\hline & 14 & 3.1 & 3 & 1.197 & 1 & 0 & 1.333 & 0.936 \\
\hline & 21 & 3.1 & 3 & 1.101 & 2.1 & 2 & 1.853 & 1.000 \\
\hline
\end{tabular}

S.D.: Standard deviation. *Statistically significant values if $p<0.05$.

Table 2. Results for the amount of mature and immature collagen at the four evaluation periods and intergroup comparisons (Kruskal Wallis test, $p<0.05$ )

\begin{tabular}{|c|c|c|c|c|c|c|c|c|}
\hline \multirow{2}{*}{ Variable } & \multirow{2}{*}{ Day } & \multicolumn{3}{|c|}{ Control group } & \multicolumn{3}{|c|}{ Experimental group } & \multirow{2}{*}{$\begin{array}{c}\mathrm{p} \\
\text { value }\end{array}$} \\
\hline & & Mean & Median & S.D. & Mean & Median & S.D. & \\
\hline \multirow{4}{*}{$\begin{array}{l}\% \text { mature } \\
\text { colagen }\end{array}$} & 3 & 10.5 & 11.0 & 0.898 & 100.0 & 100.0 & 0.000 & $0.000^{*}$ \\
\hline & 7 & 38.3 & 37.5 & 1.359 & 100.0 & 100.0 & 0.000 & $0.021^{*}$ \\
\hline & 14 & 100.0 & 100.0 & 0.000 & 100.0 & 100.0 & 0.000 & 1.000 \\
\hline & 21 & 100.0 & 100.0 & 0.000 & 100.0 & 100.0 & 0.000 & 1.000 \\
\hline \multirow{4}{*}{$\begin{array}{l}\% \\
\text { immature } \\
\text { colagen }\end{array}$} & 3 & 89.5 & 89.0 & 0.898 & 0.0 & 0.0 & 0.000 & $0.000^{*}$ \\
\hline & 7 & 61.7 & 62.5 & 1.359 & 0.0 & 0.0 & 0.000 & $0.021^{*}$ \\
\hline & 14 & 0.0 & 0.0 & 0.000 & 0.0 & 0.0 & 0.000 & 1.000 \\
\hline & 21 & 0.0 & 0.0 & 0.000 & 0.0 & 0.0 & 0.000 & 1.000 \\
\hline
\end{tabular}

S.D.: Standard deviation. *Statistically significant values if $p<0.05$. any adverse effect in control group, such as the formation of hyaline areas (13). The time during which the appliance remained in the oral cavity was based on a previous study showing that 10 to 14 days are needed for a complete cycle of PDL bone remodeling in rats (21). Although GH is widely indicated and used, there are no studies reporting its effects during tooth movement.

In $\mathrm{EG}$, there was predominance of $\mathrm{OC}$ on the $3^{\text {rd }}$ day and decline in the subsequent periods with a significant difference on the $3^{\text {rd }}$ and $14^{\text {th }}$ days compared with CG $(p<0.05)$. These results corroborate those of Tresguerres et al. (3), who verified an increase in bone resorption after 1 week of local application of $\mathrm{GH}$ in periimplant tissue. Previous studies (11-13) reported that $\mathrm{GH}$ accentuated bone remodeling turnover, stimulating resorption and osteoblast activation, resulting in new bone formation.

In $E G$, a significant decrease was observed in the number of BV compared with CG on the $3^{\text {rd }}$ and $7^{\text {th }}$ days. There are few studies that directly verified whether $\mathrm{GH}$ modulates angiogenesis, but there is evidence that when there is $\mathrm{GH}$ deficiency or excess, the vascular function could be modified (22). The polarization method combined with computerized analysis is useful to assess the GH effect in orthodontic movements and allows the correlation of the structural organization of CF (23) with the area of primary bone osteogenesis. The polarization method has been used as a possible indicator of collagen aggregation (23), but there are no studies in the literature using the picrosirius method in experiments related to orthodontic movement.

In $\mathrm{CG}$, morphometric analysis on the traction side showed immature $\mathrm{CF}$ in the initial stages, with their progressive maturation in the final stages. However, in $E G$, only mature collagen was observed, and when compared with group $C_{\text {, in }}$ the periods of 3 and 7 days, significant difference was shown. However, in vitro studies indicate that $\mathrm{GH}$ can act directly on the osteoblasts and exert anabolic effects on bone formation $(11,12)$.

This divergence could be explained by the fact that $\mathrm{GH}$ replacement may cause a two-phase effect having an initial predominance of bone resorption, and after 
12 to 24 months of treatment, stimulation of new bone formation with subsequent bone mass gain may occur ( 6 , 24). Considering these changes in the bone metabolism, it was noted that a long time of observation is needed to obtain new bone formation.

These results suggest the hypothesis that $\mathrm{GH}$ could have the ability to stimulate resorption and, probably, delay new bone formation resulting from diminished vascularization. It is known that vascular proliferation is observed in the PDL of orthodontically moved teeth, favoring the regenerative processes characteristic of this region, and is an important mediator in the bone remodeling process (25).

It is suggested that individuals undergoing orthodontic treatment and who use $\mathrm{GH}_{\text {, require longer intervals }}$ between the applications of light orthodontic forces, since the new bone formation process is delayed, and because they present more intense bone resorption, particularly in the initial stages of administration of the drug. Another recommendation would be to begin orthodontic treatment after the initial stage of $\mathrm{GH}$ administration, since it stimulates bone formation only after 12 to 24 months. Radiographic control must be frequently made to assess the status of bone resorption.

It was concluded that $\mathrm{GH}$ accelerated and intensified bone resorption and delayed immature collagen formation after experimental tooth movement in rats.

\section{Resumo}

0 objetivo deste estudo foi avaliar histologicamente o efeito do hormônio de crescimento $(\mathrm{HC})$ no ligamento periodontal e osso alveolar, durante a movimentação dentária induzida em ratos. Oitenta ratos Wistar, machos, divididos nos grupos controle e experimental, foram observados nos dias $3,7,14$ e 21. Foi aplicada força ortodôntica $(30 \mathrm{cN})$ sobre o primeiro molar superior por meio de um dispositivo ortodôntico. No grupo experimental foi administrada 0,1 UI/ $/ \mathrm{kg} / \mathrm{dia}$ de $\mathrm{HC}$ e, no grupo controle, $0,5 \mathrm{~mL} / \mathrm{kg} /$ dia de solução salina. As amostras foram processadas e avaliadas por microscopia de luz e luz polarizada. 0 teste de Kruskal Wallis foi utilizado para a comparação das variáveis intergrupos. Verificou-se que o grupo experimental apresentou maior quantidade de osteoclastos nos $3^{\circ} \mathrm{e}$ $7^{\circ}$ dias e de lacunas de Howship no $3^{\circ}$ dia, menor quantidade de vasos sanguineos e maior quantidade de colágeno maduro nos $3^{\circ} \mathrm{e} 7^{\circ}$ dias do que no grupo controle $(p<0,05)$. Concluiu-se que o $\mathrm{HC}$ acelerou e intensificou a reabsorção óssea e produziu atraso na formação de colágeno imaturo, durante o movimento ortodôntico induzido.

\section{References}

1. Ehrnborg C, Rosen T. Physiological and pharmacological basis for the ergogenic effects of growth hormone in elite sports. Asian J Androl 2008;10:373-383.

2. Parker ML, Utiger RD, Daughaday $W H$. Studies on human growth hormone. II. The physiological disposition and metabolic fate of human growth hormone in man. J Clin Invest 1962;41:262-268.

3. Tresguerres IF, Alobera MA, Baca R, Tresguerres JA. Histologic, morphometric, and densitometric study of peri-implant bone in rabbits with local administration of growth hormone. Int J Oral Maxillofac Implants, 2005;20:193-202.

4. Albertsson-Wikland K, Rosberg S. Analyses of 24-hour growth hormone profiles in children: relation to growth. J Clin Endocrinol Metab
1988;67:493-500.

5. Lanes R. Growth velocity, final height and bone mineral metabolism of short children treated long term with growth hormone. Curr Pharm Biotechnol 2000;1:33-46.

6. Simpson H, Savine R, Sonksen P, Bengtsson BA, Carlsson L, Christiansen JS, et al.. Growth hormone replacement therapy for adults: into the new millennium. Growth Horm IGF Res 2002;12:1-33.

7. Pape GS, Friedman M, Underwood LE, Clemmons DR. The effect of growth hormone on weight gain and pulmonary function in patients with chronic obstructive lung disease. Chest 1991;99:1495-1500.

8. Koea JB, Breier BH, Douglas RG, Gluckman PD, Shaw JH. Anabolic and cardiovascular effects of recombinant human growth hormone in surgical patients with sepsis. Br J Surg 1996;83:196-202.

9. Rudman D, Feller AG, Nagraj HS, Gergans GA, Lalitha PY, Goldberg AF, et al.. Effects of human growth hormone in men over 60 years old. $\mathrm{N}$ Engl J Med 1990;323:1-6.

10. Gibney J, Wallace JD, Spinks T, Schnorr L, Ranicar A, Cuneo RC, et al. The effects of 10 years of recombinant human growth hormone $(\mathrm{GH})$ in adult GH-deficient patients. J Clin Endocrinol Metab 1999;84:2596-2602.

11. Stracke H, Schulz A, Moeller D, Rossol S, Schatz H. Effect of growth hormone on osteoblasts and demonstration of somatomedin-C/IGF I in bone organ culture. Acta Endocrinol 1984;107:16-24.

12. Morel G, Chavassieux P, Barenton B, Dubois PM, Meunier PJ, Boivin G. Evidence for a direct effect of growth hormone on osteoblasts. Cell Tissue Res 1993;273:279-286.

13. Ong CK, Joseph BK, Waters MJ, Symons AL. Growth hormone receptor and IGF-I receptor immunoreactivity during orthodontic tooth movement in the prednisolone-treated rat. Angle Orthod 2001;71:486493.

14. Marcus R. Skeletal effects of growth hormone and IGF-I in adults. Horm Res 1997;48 Suppl 5:60-64.

15. Beloti MM, Rosa AL. Osteoblast differentiation of human bone marrow cells under continuous and discontinuous treatment with dexamethasone. Braz Dental J 2005;16:156-161.

16. Verna $C$, Melsen B. Tissue reaction to orthodontic tooth movement in different bone turnover conditions. Orthod Craniofac Res 2003;6:155163.

17. Oltramari PV, Conti AC, Navarro R de L, Almeida MR, Almeida-Pedrin $R R$, Ferreira FP. Importance of occlusion aspects in the completion of orthodontic treatment. Braz Dental J 2007;18:78-82.

18. Heller IJ, Nanda R. Effect of metabolic alteration of periodontal fibers on orthodontic tooth movement. An experimental study. Am J Orthod 1979;75:239-258.

19. Arias $\mathrm{OR}$, Marquez-Orozco MC. Aspirin, acetaminophen, and ibuprofen: their effects on orthodontic tooth movement. Am J Orthod Dentofacial Orthop 2006;130:364-370.

20. Macapanpan LC, Weinmann JP. The influence of injury to the periodontal membrane on the spread of gingival inflammation. J Dent Res 1954;33:263-272.

21. King GJ, Keeling SD, Wronski TJ. Histomorphometric study of alveolar bone turnover in orthodontic tooth movement. Bone 1991;12:401-409.

22. Silha JV, Krsek M, Hana V, Marek J, Weiss V, Jezkova J, et al.. The effects of growth hormone status on circulating levels of vascular growth factors. Clin Endocrinol (Oxf) 2005;63:79-86.

23. Andrade GB, Riet-Correa F, Montes GS, Battlehner CN, Saldiva PH. Dating of fibrotic lesions by the Picrosirius-polarization method. An application using the lesions of Lechiguana (bovine focal proliferative fibrogranulomatous panniculitis). Eur J Histochem 1997;41:203-209.

24. Carroll PV, Christ ER, Bengtsson BA, Carlsson L, Christiansen JS, Clemmons $D$, et al.. Growth hormone deficiency in adulthood and the effects of growth hormone replacement: a review. J Clin Endocrinol Metab 1998;83:382-395.

25. Toms A, Gannon B, Carati C. The immunohistochemical response of the rat periodontal ligament endothelium to an inflammatory stimulus. Aust Orthod J 2000;16:61-68. 